Uniwersytet im. Adama Mickiewicza w Poznaniu

\title{
Kampania wyborcza w nowych mediach - aspekty prawne
}

Dojawienie się jednego z najciekawszych zjawisk społecznych XXI w. I w obszarze komunikacji społecznej, tj. tzw. nowych mediów, musiało zostać zauważone przez sztaby wyborcze. Warto jednak zadać pytanie, czy zostało dostrzeżone i uwzględnione także przez polskiego ustawodawcę. A pretekst do tego rodzaju rozważań jest tym istotniejszy, iż w 2011 r. uchwalono ustawę z dnia 5 stycznia 2011 r. Kodeks wyborczy ${ }^{1}$.

$\mathrm{Na}$ wstępie należy wyjaśnić samo pojęcie tzw. nowych mediów ${ }^{2}$. Wedle bardzo ogólnego ujęcia (które jednak nie wiele thumaczy) są to „wszelkie techniki przekazu oraz technologie stosowane powszechnie od połowy lat 80 -tych"3. Pojawienie się tego terminu było reakcją na dynamiczny proces zmiany środków społecznego przekazu ${ }^{4}$, co z kolei wynikało ze zmian technologicznych ${ }^{5}$. W odróżnieniu od takich pojęć

1 Dz. U. Nr 21, poz. 112 z późn. zm. - dalej jako ustawa, kodeks lub k.w.

2 Wyjaśnijmy, że termin „media” obejmuje prasę, radio i telewizję (tzw. media elektroniczne) a dodatkowo kino, reklamę, fotografię, przemysł wydawniczy. Patrz szerzej M. Lister, J. Dovey, S. Giddings, I. Grant, K. Kelly, Nowe media. Wprowadzenie, Kraków 2009, s. 15; J. Skrzypczak, Polityka medialna $w$ okresie konwersji cyfrowej radiofonii i telewizji, Poznań 2011, s. 31-32; patrz też W. Welsch, Sztuczne raje? Rozważania o świecie mediów elektronicznych i o innych światach, w: Nowe media $w$ komunikacji społecznej w XX wieku. Antologia, red. M. Hopfinger, Warszawa 2002, s. 461-478.

3 Popularna encyklopedia mass mediów, red. J. Skrzypczak, Poznań 1999, s. 375. W kwestii wskazania cech charakteryzujących nowe media patrz szerzej M. Szpunar, Czym sq nowe media - próba konceptualizacji, „Studia Medioznawcze" 2008, nr 4, s. 33; T. Miczka, Nowe media jako nowe formy komunikowania politycznego i nowe formy ,, dyscyplinujacej technologii władzy”, w: Media w Polsce. Pierwsza władza IV RP, red. M. Sokołowski, Warszawa 2007, s. 186-187; J. Rawolle, T. Hess, New Digital Media and Devices. An Analysis for the Media Industry, „The International Journal on Media Management" 2000, vol. 2, no II, s. 89-98.

4 M. Szpunar, op. cit., s. 32.

5 M. Lister, J. Dovey, S. Giddings, I. Grant, K. Kelly, op. cit., s. 17-19. Autorzy zauważają, że narodziny tzw. nowych mediów wpisywały się w szersze procesy 
funkcjonujących w doktrynie jak ,,media cyfrowe”, „media elektroniczne” czy „media interaktywne”, pojęcie „nowe media” nie odnosi się do żadnego elementu czy cechy charakterystycznej przekazu, a jest przy tym na tyle pojemne, że mieści w sobie całą różnorodność zjawisk społecznych wywołanych technologiczną rewolucją cyfrową ${ }^{6}$. Zwrócić uwagę należy na pogląd prezentowany w doktrynie, że ograniczanie pojęcia nowych mediów do internetu, radiofonii i telewizji cyfrowej, multimediów, CD-Rom-ów, DVD, gier komputerowych, wirtualnej rzeczywistości, trójwymiarowych produkcji filmowych, a więc jedynie do materialnych (ewentualnie wirtualnych) desygnatów tego zjawiska, jest uproszczeniem problemu. Sugeruje się w ten sposób nowe spojrzenie na istotę tych mediów i kolejny ich wymiar, związany raczej z samą ideą i konsekwencjami społecznymi ich funkcjonowania. Spotkać można różne opinie, czym w istocie są nowe media i jakie są ich cechy wspólne $e^{7}$. Według jednego z ujęć termin ten miałby oznaczać: „a) nowe doświadczenia tekstualne [...] (nowe rodzaje form gatunkowych), b) nowe sposoby reprezentacji świata (np. multimedia) [...], c) nowe relacje pomiędzy podmiotami (użytkownikami i konsumentami) oraz technologiami medialnymi (np. komunikacja) [...], d) nowe doświadczenia pomiędzy cielesnością, tożsamością i społecznością [...], e) [...] tworzenie bytów wirtualnych, f) nowe wzorce organizacji i produkcji (nowe zasady do-

i zmiany społeczne zachodzące od lat sześćdziesiątych XX stulecia, takie jak „,przejście od modernizmu do postmodernizmu [...], nasilające się procesy globalizacji [...], przejście od industrialnej ery produkcji do postindustrialnej ery informacji [...], decentralizacja ugruntowanych i scentralizowanych systemów geopolitycznych". Ibidem, s. 18.

${ }^{6}$ Można tu dodać jeszcze takie pojęcie występujące w doktrynie jak ang. Computer-Mediated Communication (CMC) czyli komunikowanie się za pośrednictwem komputera. Zob. szerzej M. Lister, J. Dovey, S. Giddings, I. Grant, K. Kelly, op. cit., s. 19. Patrz także J. Van Cuilenburg, On Competition, Access and Diversity in Media, Old and New: Some Remarks for Communications Policy in the Information Age, „New Media \&Society” 1999, no 1, s. 184-205.

7 Zob. szerzej J. V. Pavlik, Journalism and New Media, New York-Chichester-West Sussex, 2001, s. XI-XVI, 3-16; P. Flichy, New Media History, w: The Handbook of New Media, eds. L. A. Lievrouw, S. Livinstones, London 2004, s. 136-150; T. Feldman, An Introduction to Digital Media, London 1997, s. 1-21; K. Dyson, P. Humphreys, R. Negrine, J. P. Simon, Broadcasting and New Media Policies in Western Europe, London 2002, s. 1-61; J. Skrzypczak, Polityka..., s. 31-34. 


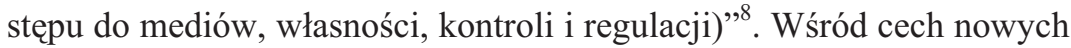
mediów wskazywano także cyfrowość, interaktywność ${ }^{9}$, hipertekstualność, wirtualność, usieciowienie ${ }^{10}$ i symulowanie ${ }^{11}$. Jeszcze inni ${ }^{12}$ dostrzegają takie ich cechy jak: reprezentacja numeryczna (czyli wyrażenie w postaci cyfrowej), modularnośśc ${ }^{13}$, automatyzacja (dotycząca procesu tworzenia, obróbki i udostępniania), wariacyjność (nowe media istnieją w wielu odmiennych od siebie wersjach), transkodowanie (tzn. nowe

8 M. Lister, J. Dovey, S. Giddings, I. Grant, K. Kelly, op. cit., s. 21.

9 Warto zwrócić uwagę, że interaktywność może być rozpatrywana na różnych płaszczyznach. I tak wskazać można interaktywność transmisyjną (tj. możliwość wyboru przez odbiorcę określonych treści z całej bogatej oferty mediów wielokanałowych, ale bez możliwości składania życzeń za pomocą kanału zwrotnego), interaktywność konsultacyjną (np. VoD), interaktywność konwersacyjną (możliwość odbierania tworzonych przez odbiorcę informacji, ich rejestrowanie np. mailing) oraz interaktywność rejestracyjną (tj. umiejętność dostosowania się do spersonalizowanych oczekiwań odbiorcy np. inteligentne EPG, przeglądarki internetowe). Zob. Z. Bauer, Dziennikarstwo i nowe media, w: Media audiowizualne. Podręcznik akademicki, red. W. Godzic, Warszawa 2010, s. 187-188.

${ }^{10}$ Usieciowanie utożsamiane jest z globalizacją. Dotyczy to w szczególności sieci teleinformacyjnych, tworzących światową sieć. To jednak rodzi zupełnie nowe problemy, chociażby w sferze prawnej. Z punktu widzenia porządków prawnych, ta możliwość powoduje, że skuteczność dochodzenia prawa, staje się problematyczna. Choć podejmuje się pewne próby przeciwdziałania tym niedogodnością. Wzbudza to jednak ogromne kontrowersje. Por. chociażby dyskusję prowadzoną w związku tzw. ACTA. Patrz szerzej J. B. Thompson, Media i nowoczesność. Społeczna teoria mediów, Wrocław 2001, s. 175-179; B. Kosmalska, Telewizja a globalizacja kultury, w: Media i spoleczeństwo. Nowe strategia komunikacyjne, red. M. Sokołowski, Torun 2008, s. 202-210. Podkreślono, że globalizacja rynków medialnych odbywa się w sferze odbioru, treści, finansowania, regulacji prawnych i poziomu strukturalnego. Ibidem, s. 203-204; patrz także J. Olędzki, Komunikowanie w świecie, Warszawa 2001, s. 158 oraz M. Gajlewicz, Internet a globalizacja, „Studia Medioznawcze" 2003, nr 3, s. 20-21.

${ }^{11}$ Zob. szerzej K. Dyson, P. Humphreys, R. Negrine, J. P. Simon, op. cit., s. 22-71. Z kolei zdaniem L. Manovicha „Nowe media są wynikiem przecięcia dwu odrębnych procesów - historii technik obliczeniowych i historii technologii medialnych". L. Manovich, Język nowych mediów, Warszawa 2006, s. 82; M. Drożdż, Media. Teorie i fikcje, Kielce 2005, s. 149-151.

${ }^{12} \mathrm{~W}$ opinii Z. Bauera nowe media charakteryzują się „hipertekstową strukturą przekazu i odbioru, możliwością programowania (asynchronią nadawania i odbioru), interaktywnością, kumulatywnością, globalnym zasięgiem i jednocześnie indywidualizacją dostępu". Tak Z. Bauer, Dziennikarstwo i nowe media, op. cit., s. 167.

${ }^{13}$ Albo mówiąc inaczej fraktalna struktura nowych mediów, tj. taka, która nie zmienia się w zależności od skali. 
media składają się z warstwy komputerowej i warstwy kulturowej) ${ }^{14}$. Jeszcze inni podkreślają, że $\mathrm{w}$ ten sposób rozpoczyna się nowa era mediów, tzw. „trzecia fala”, prowadząca w okres odmasowionych środków komunikacji ${ }^{15}$ i nasilającej się ich ,specjalizacji i segmentacji, a co za tym idzie, zacieraniem granic między producentami a konsumentami"16. Proponując kategorię nowych mediów wskazuje się w ten sposób pewną opozycję $^{17}$, a mianowicie ,nowe media - stare media (ewentualnie tra-

${ }^{14}$ L. Manovich, op. cit., s. 92-118. Zob. także P. Celiński, Interfejsy nowych mediów i refiguracje mediów i kultury, w: Nowe media a media tradycyjne. Prasa, reklama, Internet, red. M. Jeziński, Torun 2009, s. 11-19.

${ }_{15}$ Zob. szerzej A. Toffler, Odmasowione środki przekazu, w: Nowe..., red. M. Hopfinger, op. cit., s. 447. O innych aspektach i konsekwencjach nowych mediów zob. R. Dziemba, Nowe media a koncepcja „piatej władzy”, w: Nowe media i polityka. Internet, demokracja, kampanie wyborcze, red. M. Jeziński, Toruń 2009, s. 53-61; A. Grzesik-Robak, Media tradycyjne wobec nowych rozwiazań technologicznych - szansa czy zagrożenie, w: Nowe media i polityka..., red. M. Jeziński, op. cit., s. 27-35; A. Młynarska-Sobaczewska, A. Preisner, Rozwój technologiczny a przyszłość demokracji, w: Czlowiek i społeczeństwo wobec wyzwań wspótczesności. Aspekty kulturowe i spoteczne, red. D. Gizicka, W. Gizicki, Torun 2008, s. 113-127; J. W. Palmer, L. Eriksen, Digital News - Paper, Broadcast and More Converge on the Internet, „The International Journal on Media Management” 1999, vol. 1, no 1, s. 32 .

${ }^{16}$ M. Lister, J. Dovey, S. Giddings, I. Grant, K. Kelly, op. cit., s. 49. Zob. Także K. H. Veltman, Understanding New Media. Augmented Knowledge\&Culture, Calgary 2006, s. 3-47. Ten autor podkreśla takie cechy nowych mediów jak komputeryzacja, mobilność, miniaturyzacja. Patrz także T. Kowalski, Wprowadzenie do analizy struktury przemyslu nowych mediów, „Studia Medioznawcze” 2003, nr 3, s. 23-30. Zdaniem innych autorów podział na stare i nowe media staje się coraz bardziej anachroniczny, zważywszy że cechą wyróżniającą nowe media miał być model nazywany Computer Mediated Communication, oparty na komputerze. Obecnie wskazuje się na tzw. standard komunikacji zmediatyzowanej. Media stały się multimediami. Wskazuje się, że istotą problemu jest okoliczność, że media cyfrowe zmieniają model komunikacji z konstrukcji „nadawca-medium-odbiorca” na „serwer-klient”. Stąd - wedle tej koncepcji - można mówić o deżurnalizacji, a więc eliminowaniu z tego procesu „żywego” pośrednika. K. Krzysztofek, Status mediów cyfrowych: stare i nowe paradygmaty, w: Studia nad komunikacja popularna, międzykulturowa, sieciowq i edukacyjnq, red. J. Fras, Toruń 2007, s. 223-224. Zob. także J. Skrzypczak, Polityka..., op. cit., s. 32-34.

${ }^{17}$ Nie oznacza to jednak, że nowe media muszą wyprzeć stare. I tak zwolennicy koncepcji kultury konwergencji przekonują, że stare i nowe media będą się wzajemnie uzupełniały, wchodząc w rozmaite interakcje. Poglądy te relacjonuje M. Mrozowski, System medialny, s. 63. Patrz także H. Jenkins, op. cit., s. 45. Wydaje się, że takie stanowisko prezentuje także U. Eco, Nowe środki masowego przekazu a przy- 
dycyjne)"18. Trzeba tu wyjaśnić, iż ,[...] przekaz cyfrowy istotnie różni się od przekazu analogowego, w którym wszystkie dane wejściowe są przekształcane na inne obiekty materialne. Określenie analogowe odnosi się tu do sposobu, w jaki dane wejściowe (światło odbite od nierównej powierzchni, żywy dźwięk czyjegoś śpiewu, znaki zapisane czyjąś ręką) oraz zakodowany produkt medialny (rowki na płycie winylowej lub układ cząstek magnetycznych na taśmie) pozostają w stosunku do siebie w relacji analogicznej [...] oraz do procesów, w których jeden rodzaj właściwości fizycznych może być przechowywany w innej, analogicznej formie materialnej. [...] W przypadku mediów cyfrowych, fizyczne właściwości danych wejściowych, światła i fal dźwiękowych, nie są przekształcane na inne obiekty, lecz na cyfry, czyli na symbole abstrakcyjne, zamiast na przedmioty analogowe i materialne powierzchnie"19. $\mathrm{Z}$ punktu widzenia niniejszego opracowania na szczególną uwagę zasługują te media, które dostępne są w internecie. Wyjaśnić przy tym trzeba, że internet nie jest sam w sposobie żadnym nowym, odrębnym medium, a jedynie kanałem dystrybucji nowych mediów ${ }^{20}$.

szłość ksiqżki, w: M. Hopfinger (red.), op. cit., s. 537-544. Wedle koncepcji netokracji natomiast rola starych mediów zostanie sprowadzona do dostarczycieli treści w sieciowych piramidach. A. Bard, J. Söderqvist, Netokracja. Nowa elita władzy $i$ życie po kapitalizmie, Warszawa 2006, s. 86. Zob. także J. Skrzypczak, Polityka..., op. cit., s. 32-34.

18 Wydaje się, że twierdzenie podnoszone przez niektórych badaczy, iż pojęcie nowych mediów obejmuje jedynie te środki społecznego przekazu, które wykorzystują łącza internetowe, jest zbyt dużym uproszeniem. (tak np. M. Wnorowska, Nowe media $w$ okresie hibernacji politycznej, w: Nowe media i polityka..., red. M. Jeziński, s. 113). Trzeba bowiem podkreślić, że internet jest tylko jedną z platform dostarczenia treści mediów cyfrowych. A takich płaszczyzn dzięki technologii cyfrowej jest wiele. Dlatego też z pewnością do kategorii nowych mediów można zakwalifikować radiofonię i telewizję cyfrową, nawet jeżeli dostarczana jest w sposób naziemny rozsiewczy. Podobnie nie można zgodzić się z twierdzeniem, że nowe media to tylko te, które umożliwiają komunikację za pomocą komputera. Tak J. Nowak, Cyfrowy maoizm czy zbiorowa inteligencja? Debata w nowych mediach - stanowiska teoretyczne i aktualna dyskusja, w: Wspótczesne media. Status, aksjologia, funkcjonowanie, red. I. Hofman, D. Kępa-Figura, t. II, Lublin 2009, s. 214. Wedle tego poglądu telewizja cyfrowa nie mieści się w katalogu nowych mediów. Choć przecież odbiornik telewizyjny coraz bardziej upodabnia się do komputera, zwłaszcza jeżeli mowa jest o teleputerze. Zob. także J. Skrzypczak, Polityka ..., op. cit., s. 32-34.

19 M. Lister, J. Dovey, S. Giddings, I. Grant, K. Kelly, op. cit., s. 25-27 oraz L. Manovich, op. cit., s. 84-90.

${ }^{20}$ Zob. także J. Skrzypczak, Polityka..., op. cit., s. 32-34. 
Po okresie dwudziestolecia doświadczeń z wyborami demokratycznymi w Polsce, przyjęto nowy akt prawny regulujący prawo wyborcze w Polsce, tj. Kodeks wyborczy ${ }^{21}$, a więc już czasie powszechnego stosowania technologii cyfrowych. Stąd też należy poddać analizie przepisy zawarte w tym akcie normatywnym, w kontekście oceny ich dostosowania do nowych technologii wykorzystywanych już na szeroką skalę w kampaniach wyborczych.

Wyjaśnić tu także trzeba, że obowiązująca ustawa - podobnie zresztą jak uchylone tym aktem normatywnym ordynacje wyborcze $\mathrm{e}^{22}$ - stanowi, iż okres kampanii wyborczej ${ }^{23}$ rozpoczyna się z dniem ogłoszenia aktu właściwego organu o zarządzeniu wyborów i ulega zakończeniu na 24 godziny przed dniem głosowania. Zgodnie z art. $107 \S 1 \mathrm{w}$ dniu głosowania oraz na 24 godziny przed tym dniem prowadzenie agitacji wyborczej (np. wygłaszanie przemówień oraz rozpowszechnianie materiałów

21 Ustawa z dnia 5 stycznia 2011 r. Kodeks wyborczy (Dz. U. Nr 21, poz. 112 z późn. zm. - dalej jako ustawa, kodeks lub k.w.). Na marginesie warto zwrócić uwagę, że już sama nazwa tego aktu normatywnego budziła wątpliwości i zastrzeżenia. W związku z tym, warto przywołać pogląd zaprezentowany w zdaniu odrębnym sędziego TK Marka Zubika do wyroku Trybunału Konstytucyjnego z dnia 20 lipca 2011 r. (sygn. akt K 9/11) - dalej jako wyrok TK. „Należy podkreślić, że pojęcie kodeksu ma ustabilizowane znaczenie w europejskiej kontynentalnej kulturze prawnej i dotyczy aktu, który w sposób kompleksowy reguluje wyodrębnioną dziedzinę życia społecznego, mając na celu stabilizację stanu prawnego. Kodeks wyborczy, mimo swej nazwy, nie spełnia tego kryterium. Stanowi bowiem faktyczne - a w wielu miejscach, niestety, niezbyt udane - zsumowanie dotychczasowych przepisów prawa wyborczego, które nie prowadzi do unifikacji tej gałęzi prawa, ale jednocześnie powoduje poważne wątpliwości interpretacyjne". Pogląd ten należy w pełni podzielić.

22 Ustawa o wyborze Prezydenta Rzeczypospolitej Polskiej z dnia 27.09.1990 (t.j. Dz. U. 2000, Nr 47, poz. 544; Dz. U. Nr 67, poz. 398 późn. zm.); Ordynacja wyborcza do rad gmin, rad powiatów i sejmików województw z dnia 17.07.1998 r. (t.j. Dz. U. 2003, Nr 159, poz. 1547 późn. zm.); Ordynacja wyborcza do Sejmu Rzeczypospolitej Polskiej i do Senatu Rzeczypospolitej Polskiej z dnia 12.4.2001 r. (Dz. U. $\mathrm{Nr}$ 46, poz. 499 z późn. zm.); ustawa o bezpośrednim wyborze wójta, burmistrza i prezydenta miasta z dnia 20.06.2002 r. (Dz. U. 2002, Nr 113, poz. 984); ustawa Ordynacja wyborcza do Parlamentu Europejskiego z dnia 23.01.2004 r. (Dz. U. $2004 \mathrm{Nr} 25$, poz. 219).

23 Pojęcie kampanii wyborczej definiowane jest jako „, zorganizowany zespół energicznych działań i prac objętych urzędowo ustalonym czasem i w prawnie określonych formach, zmierzających do uzyskania jak najlepszego wyniku w wyborach", F. Rymarz w: K. Czaplicki, B. Dauter, A. Kisielewicz i F. Rymarz, Samorzadowe prawo wyborcze, Warszawa 2010, s. 234; M. Chmaj, W. Skrzydło, System wyborczy w Rzeczypospolitej Polskiej, Warszawa 2008, s. 81-82. 
wyborczych) jest zabronione. Zważywszy na wspominany już wcześniej globalny charakter internetu, wydaje się, że skuteczność tego rodzaju ograniczeń jest co najmniej problematyczna. I nie chodzi tu tylko o działania celowe, kiedy ktoś celowo umieszcza materiały wyborcze na zagranicznym serwerze, aby ominąć powyższe ograniczenia. Ale kłopotliwe może być także ustalenie wedle jakiej strefy czasowej, należy ustalać formalny koniec kampanii wyborczej. Jak wyjaśnił Sąd Najwyższy w uzasadnieniu postanowienia z dnia 28 listopada 2007 r. $^{24}$, ,zakaz podawania do wiadomości publicznej wstępnych sondażowych wyników wyborów (opartych na meldunkach o częściowych rezultatach wyborów, sporządzanych na podstawie wyników zbieranych przez ankieterów przeprowadzających wywiady z wyborcami opuszczającymi lokale wyborcze) obowiązuje do czasu zakończenia ciszy wyborczej w Polsce". Jak z powyższego wynika, ramy czasowe kampanii wyborczej należy badać w kontekście strefy czasowej obowiązującej w Polsce. Ponadto można twierdzić, że cisza wyborcza o której mowa w przywoływanym powyżej przepisie, obowiązuje jedynie w Polsce. Zresztą przyznajmy, że inne ujęcie byłoby i tak niemożliwe do osiagnięcia, zważywszy chociażby na właściwość prawa krajowego ${ }^{25}$. Z taką wykładnią koresponduje treść art. $115 \S 1$ k.w., wprowadzającego ciszę wyborczą ${ }^{26}$. Otóż przypomnieć należy, że zgodnie z tym przepisem na 24 godziny przed dniem głosowania aż do zakończenia głosowania, zabrania się podawania do publicznej wiadomości wyników przedwyborczych badań (sondaży) opinii publicznej dotyczących przewidywanych zachowań wyborczych i wyników wyborów oraz wyników sondaży wyborczych przeprowadzanych w dniu głosowania. W § 2 tego przepisu wyraźnie przesądzono, że przepis ten stosuje się wyłącznie na terytorium Rzeczypospolitej Polskiej. Co interesujące, zważywszy na omawianą tu problematykę, podkreśla się w doktrynie, iż „wszelkie formy podawania do wiadomości

24 Postanowienie z dnia 28 listopada 2007 r. III SW 52/07; tekst opublikowano na stronie http://prawo.money.pl/orzecznictwo/sad-najwyzszy/postanowienie;sn;izba;pracy;ubezpieczen;spolecznych;i;spraw;publicznych,ia,iii,sw,52,07,8415,orzeczenie.html.

25 Trzeba przyznać, że pojawiają się nawet wątpliwości jakie prawo byłoby w takim przypadku właściwe. Z pewnością nie będą miały zastosowania w tym zakresie postanowienia ustawy z dnia 4 lutego 2011 r. Prawo międzynarodowe prywatne (Dz. U. Nr 80, poz. 432 z późn. zm.), bowiem zgodnie z art. 1 ten akt normatywny reguluje właściwość prawa wyłącznie dla stosunków z zakresu prawa prywatnego.

${ }_{26}$ Co do definicji ciszy wyborczej (przedwyborczej) patrz B. Michalak, A. Sokala, Leksykon prawa wyborczego i systemów wyborczych, Warszawa 2010, s. 20. 
publicznej [...] wyników sondaży, dotyczą [...] również nadawców w internecie. Traktując internet na równi z prasą, przyjmuje się, że pozostawienie wcześniej umieszczonych treści na stronach internetowych (tak jak w prasie) nie narusza [...] ustawy"27.

Kodeks zakazuje agitacji wyborczej w lokalu wyborczym oraz na terenie budynku, w którym ten lokal się znajduje. W art. $105 \S 1$ k.w. zdefiniowano, iż agitacją wyborczą jest publiczne nakłanianie lub zachęcanie, do głosowania w określony sposób lub do głosowania na kandydata określonego komitetu wyborczego. Jak widać, wzorem uchylonych ordynacji wyborczych, także kodeks wyborczy rozróżnia pojęcia kampanii wyborczej i agitacji wyborczej. Przypomnieć w tym miejscu należy, że identyczne rozwiązanie przyjęto $w$ art. 85 ust. 3 ordynacji wyborczej do Sejmu i do Senatu ${ }^{28}$. Z pewnością także w obowiązującym akcie normatywnym pojęcie kampanii wyborczej jest szersze niż termin agitacja wyborcza. Jak się wydaje, to pierwsze pojęcie należy wiązać z pewnym okresem, natomiast agitację należy utożsamiać raczej z określoną formą aktywności. Takie rozróżnienie jest o tyle istotne, że art. 494 k.w. penalizuje niedozwolone przejawy agitacji wyborczej. Przywołane przepisy zabraniają zatem agitacji bez względu na formę i środki wyrazu. Odnosić się zatem będzie do wszelkiego rodzaju przemówień, rozrzucania ulotek, ale także działań z udziałem nowych technologii, np. emitowaniu spotów reklamowych z różnego rodzaju nośników cyfrowych. W doktrynie zwracano jednak uwagę, że zabronionym czynem jest działanie tego rodzaju, które jest przejawem pewnej aktywności ${ }^{29}$. Nie oznacza to zatem konieczności usuwania np. rozlepionych plakatów. I w tym zakresie trzeba przyznać, że podobne wątpliwości mogłyby dotyczyć elektronicznych form ekspresji wyborczej. Wydaje się, że nawet wcześniej zlecone czynności w sferze cyfrowej, zawsze należałoby utożsamiać z określoną formą aktywności, nawet jeżeli za powtarzalność pewnych czynności odpowiedzialny jest komputer i program komputerowy, a nie człowiek. Stąd też, w obowiązującym stanie prawnym, opowiedzieć trzeba się za zakazem tego rodzaju środków wyrazu w okresie ciszy wyborczej.

27 F. Rymarz, op. cit., s. 241.

$28 \mathrm{Na}$ tle tego przepisu w doktrynie wskazywano zróżnicowanie zakresu terminu kampania wyborcza od agitacji wyborczej. Podkreślono, że ten pierwszy termin należało rozumieć szerzej. Por. S. Gebethner, Wybory do Sejmu i do Senatu, Warszawa 2001, s. 120; idem, Wybory na urzad Prezydenta Rzeczypospolitej Polskiej, Warszawa 2001 , s. $153-154$.

29 Idem, Wybory na urzad..., op. cit., s. 154. 
W kontekście omawianej tu problematyki wątpliwości mogą rodzić na tle wykładni art. $105 \S 2$ k.w. Przypomnijmy, iż na mocy tego przepisu zezwolono na prowadzenie agitacji wyborczej dopiero od dnia przyjęcia przez właściwy organ zawiadomienia o utworzeniu komitetu wyborczego. Ten fragment przepisu nie budzi większych wątpliwości. Natomiast zastrzeżenia mogą się rodzić na tle dalszej jego części. Stanowi on bowiem, że agitację wyborczą można prowadzić jedynie na zasadach, w formach i w miejscach określonych przepisami kodeksu wyborczego. Gdyby przyjąć restrykcyjną wykładnię tego przepisu, należałoby twierdzić, że tylko w formach taksatywnie w nim wskazanych, można prowadzić agitację. Jeżeli tak to koniecznym byłoby też zdefiniowanie, co należy rozumieć pod pojęciem „formy prowadzenia kampanii wyborczej”. Choć podobne zapisy pojawiły się w uchylonych ordynacjach, to jednak ani w doktrynie, ani w judykaturze bliżej nie wyjaśniono tego terminu. Wydaje się jednak, że pojęcie „forma prowadzenia agitacji wyborczej" nie może być utożsamiane z analogową lub cyfrową formą wyrazu i uzewnętrznienia określonych pomysłów. W świetle komentowanych przepisów, byłoby to zupełnie nieuzasadnione i niecelowe ograniczenie wolności ekspresji politycznej. Opowiedzieć należy się zatem za szerokim rozumieniem tego pojęcia, poprzez przyjęcie raczej negatywnego ujęcia zakresu tego pojęcia. Oznacza to, że dozwolone są wszelkie formy wyrazu, poza wyraźnie zakazanymi.

Jako przykład należy wskazać art. 108 k.w., który zabrania prowadzenia agitacji wyborczej na terenie urzędów administracji rządowej i administracji samorządu terytorialnego, sądów, jednostek wojskowych i innych jednostek organizacyjnych podległych Ministrowi Obrony Narodowej oraz oddziałów obrony cywilnej, a także skoszarowanych jednostek podległych ministrowi właściwemu do spraw wewnętrznych, na terenie szkół wobec uczniów ${ }^{30}$. Natomiast na terenie innych zakładów pracy zakazane jest prowadzenie takiej działalności w sposób i w formach zakłócających ich normalne funkcjonowanie. Na tle tego przepisu trzeba podkreślić kwestię, która tylko na pierwszy rzut oka wydaje się oczywista. Otóż powyższy przepis zakazuje ,prowadzenia” agitacji wy-

30 Przy czym kodeks wyborczy wyjaśnił, że za agitację wyborczą nie uznaje się prowadzonych przez szkołę zajęć z zakresu edukacji obywatelskiej polegających na upowszechnianiu wśród uczniów wiedzy o prawach i obowiązkach obywateli, znaczeniu wyborów w funkcjonowaniu demokratycznego państwa prawa oraz zasadach organizacji wyborów. 
borczej na terenie wyżej wymienionych jednostek. Rzecz jasna chodzi tu o rzeczywiste, fizyczne działania, a nie przypadki, gdy działalność taka prowadzona jest za pomocą mediów, w tym cyfrowych.

Kodeks wyborczy zabrania komitetom wyborczym, kandydatom oraz wyborcom organizowania loterii fantowych, innego rodzaju gier losowych oraz konkursów, w których wygranymi są nagrody pieniężne lub przedmioty o wartości wyższej niż wartość przedmiotów zwyczajowo używanych w celach reklamowych lub promocyjnych. Ten przypadek dotyczyć będzie również środowiska cyfrowego. Choć znów możliwości internetu, jako sieci globalnej powodują, że skuteczność tych ograniczeń może być iluzoryczna. Podobnie należy ocenić przepis zabraniający dostarczania, w ramach prowadzonej agitacji wyborczej, napojów alkoholowych nieodpłatnie lub po cenach sprzedaży netto możliwych do uzyskania, nie wyższych od cen nabycia lub kosztów wytworzenia. Dostarczanie o którym mowa $\mathrm{w}$ tym przepisie obejmować $\mathrm{z}$ pewnością będzie także przesyłanie za pomocą przesyłek pocztowych i kurierskich. Także i w tym przypadku skuteczność tego zakazu wobec podmiotów działających poza granicami kraju jest problematyczna.

Z kolei zgodnie z art. $109 \S 3$ k.w. materiały wyborcze podlegaja ochronie prawnej. W $\S 1$ tego przepisu zdefiniowano, iż materiałem wyborczym jest każdy pochodzący od komitetu wyborczego upubliczniony i utrwalony przekaz informacji mający związek z zarządzonymi wyborami. Stosunkowo najłatwiej wyjaśnić przesłankę ,pochodzący od komitetu wyborczego". W tym przypadku chodzi o każdy materiał wytworzony lub akceptowany przez komitet wyborczy. Tego wymogu nie spełni zatem tekst zamieszczony w prasie agitujący na rzecz konkretnego komitetu wyborczego, ale pochodzący od redakcji. Natomiast pojawić moga się ogromne wątpliwości jak należy rozumieć wymóg „upublicznienia” i „utrwalenia” w kontekście przekazów cyfrowych. Żadne z tych pojęć nie zostało zdefiniowane. Jeżeli chodzi o przesłankę „upublicznienia” to wydaje się, że należy przyjać, iż chodzi tu o każdy przypadek, gdy określone treści zostały (przynajmniej potencjalnie) udostępnione nieograniczonemu kręgowi odbiorców. W takim ujęciu nie ma wątpliwości, że w przypadku zastosowania tradycyjnego schematu komunikowania masowego, tzn. układu one-to-many ${ }^{31}$, warunek ten zostanie spełniony.

31 Wyjaśnić tu należy, że jednym ze skutków cyfryzacji mediów, jest rozróżnienie pomiędzy takimi pojęciami jak broadcasting a narrowcasting. Pierwszy z tych terminów oznacza tradycyjnie taką emisję programów, która polega na tym, że 
I nie ma znaczenia, czy odbywa się to w przekazie analogowym czy cyfrowym, w ramach mediów tradycyjnych czy tzw. społecznościowych ${ }^{32}$. Większe wątpliwości dotyczą przekazów odbywających się w schemacie one-to-one. Różnorodność zjawisk ery cyfrowej powoduje, że właściwie każdy przypadek należy traktować oddzielnie. Jako przykład niech posłuży mailing, który w istocie jest rozsyłaniem listów drogą elektroniczną. Wydaje się jednak, że w przypadku, gdy za pomocą poczty elektronicznej przekazuje się te same treści do szerokiego grona osób, choć adresując odrębny list do konkretnego adresata, można twierdzić, iż przesłanka upublicznienia zostaje spełniona. Natomiast przekazanie pojedynczego listu elektronicznego do konkretnie wskazanego odbiorcy, tego wymogu nie spełnia. Z kolei w przekazach zindywidualizowanych, w których odbiorca sam profiluje sobie otrzymywany przekaz, w oparciu o wspólną bazę contentu, przesłanka ta będzie zrealizowana. Odrębnym zagadnieniem są przekazy na żądanie ${ }^{33}$. W tym przypadku, każdy z odbiorców

nadawca transmituje program do odbioru publicznego (schemat one-to-many). Narrowcasting z kolei charakteryzuje się schematem one-to-one, czyli od nadawcy do konkretnego odbiorcy. Pozwala to na dostarczanie programu zindywidualizowanego, będącego odpowiedzią na zapotrzebowanie konkretnego słuchacza lub widza.

32 Pojęcie mediów (dziennikarstwa) społecznościowych jest zjawiskiem bardzo zróżnicowanym. Pojawiają się różne tłumaczenia np. ang. określenia grassroot media, używa się także takich określeń jak dziennikarstwo „oddolne” lub „amatorskie” (zob. uwagi thumacza w H. Jenkins, op. cit., s. 8). Funkcjonują także w doktrynie takie terminy jak ,dziennikarstwo obywatelskie” (citizen journalism), „dziennikarstwo uczestniczące” (participatory journalism), „cywilne dziennikarstwo” (civic journalism) albo „czarnorynkowe” (black market journalism). Patrz W. Pisarek, Wstęp, s. 154 oraz Z. Bauer, Dziennikarstwo, s. 191-192. Zdaniem tego ostatniego autora, cechy charakterystyczne tego rodzaju dziennikarstwa to zaangażowanie dotychczasowej publiczności w proces tworzenia i publikowania treści, możliwość wspólnego tworzenia przekazów, ograniczona kontrola nad tekstami z uwagi na wielość podmiotów występujących procesie ich kreacji, dystrybucja treści za pomocą innych platform niż media tradycyjne. Ibidem, s. 192.

33 Rozwój technologii prowadzi także do stworzenia nowej kategorii przekazów, tzw. nielinearnych. Następuje zmiana pasywnego komunikowania linearnego w aktywne przekazy nielinearne. Obserwować można w ten sposób komunikację asynchroniczną w tym sensie, że treści mogą być dostępne w momencie i miejscu wybranym swobodnie przez odbiorcę. Usługami linearnymi nazywa się te postaci programów radiowych i telewizyjnych, które są dostarczane poprzez takie formy dystrybucji jak: radiodyfuzja naziemna (zarówno analogowa, jak i cyfrowa), streaming, programy dostarczane poprzez internet (webcasting) lub poprzez telefony komórkowe, a także tzw. NVoD. Pod pojęciem usług nielinearnych rozumie się umożliwianie dostępu do określonej treści w czasie i miejscu przez odbiorcę wybra- 
wybiera czas i miejsce odbioru treści, tym niemniej także i w tym przypadku wydaje się, że możemy mówić o upublicznieniu. Nawet wówczas, gdy z określonej zawartości skorzysta tylko jedna osoba. Podobnych kłopotów przysparza w środowisku cyfrowym przesłanka utrwalenia. Zresztą ten wymóg może dziwić nawet w kontekście analogowego przekazu, bowiem czy można odmawiać takiego statusu komunikatom przekazywanym przez komitet wyborczy „na żywo”?. Wydaje się, że lepszym rozwiązaniem było zastosowanie terminu „ustalenie" w rozumieniu art. 1 prawa autorskiego ${ }^{34}$. W tym przypadku ustalenie to ,uzewnętrznienie" utworu, które umożliwia percepcję określonych treści przez inną osobę, dokonane w jakiejkolwiek postaci. Natomiast w rozumieniu prawa autorskiego utrwalenie to trwałe ustalenie na nośniku materialnym, który umożliwia wielokrotne odtwarzanie i percepcję tych samych treści $^{35}$. Powyższe uwagi i ustalenie czy dany materiał jest materiałem wyborczym są o tyle istotne, że cytowany przepis wymaga, aby materiały wyborcze zawierały wyraźne oznaczenie komitetu wyborczego, od którego pochodzą. Dotyczy to - rzecz jasna- wszystkich form przekazu informacji.

Wydaje się natomiast, że art. $110 \S 1$ k.w. nie znajdzie zastosowania w środowisku cyfrowym, a zwłaszcza internetowym ${ }^{36}$. Konkluzja ta do-

nym. Do tej kategorii zalicza się takie rozwiązanie jak Video on Demand (VoD) lub Radio on Demand. Patrz szerzej, J. Skrzypczak, Polityka..., op. cit., s. 31.

${ }^{34}$ Ustawa z dnia 4 lutego 1994 r. o prawie autorskim i prawach pokrewnych (t.j. Dz. U. 2006, Nr 90, poz. 631 z późn. zm.).

35 Jako przykłady utrwalenia w rozumieniu prawa autorskiego należy wskazać druk, zapis magnetyczny, cyfrowy, wykonanie fotografii itp.

${ }^{36}$ Przypomnieć należy, że zgodnie z art. $110 \S 1$ k.w. „Na ścianach budynków, przystankach komunikacji publicznej, tablicach i słupach ogłoszeniowych, ogrodzeniach, latarniach, urządzeniach energetycznych, telekomunikacyjnych i innych można umieszczać plakaty i hasła wyborcze wyłącznie po uzyskaniu zgody właściciela lub zarządcy nieruchomości, obiektu albo urządzenia. § 2. Przy ustawianiu własnych urządzeń ogłoszeniowych w celu prowadzenia kampanii wyborczej należy stosować obowiązujące przepisy porządkowe. Przepis art. 109 stosuje się odpowiednio. § 3. Plakaty i hasła wyborcze należy umieszczać w taki sposób, aby można je było usunąć bez powodowania szkód. § 4. (utracił moc). §5. Policja lub straż gminna jest obowiązana usuwać na koszt komitetów wyborczych plakaty i hasła wyborcze, których sposób umieszczenia może zagrażać życiu lub zdrowiu ludzi albo bezpieczeństwu mienia bądź bezpieczeństwu w ruchu drogowym. § 6. Plakaty $i$ hasła wyborcze oraz urządzenia ogłoszeniowe ustawione w celu prowadzenia agitacji wyborczej pełnomocnicy wyborczy obowiązani są usunąć w terminie 30 dni po dniu wyborów. § 7. Wójt postanawia o usunięciu plakatów i haseł wyborczych oraz 
tyczy także upoważnienia dla policji i straży miejskiej do usuwania na koszt komitetów wyborczych plakatów i haseł wyborczych, których sposób umieszczenia może zagrażać życiu lub zdrowiu ludzi albo bezpieczeństwu mienia bądź bezpieczeństwu w ruchu drogowym, jak również obowiązku ciążącym na pełnomocnikach wyborczych usunięcia plakatów i haseł wyborczych oraz urządzeń ogłoszeniowych ustawionych w celu prowadzenia agitacji wyborczej w terminie 30 dni po dniu wyborów.

Kodeks wyborczy wzorem uchylonych ordynacji wyborczych przewiduje także szczególny, bo szybki tryb postępowania sądowego ${ }^{37}$. Otóż zgodnie z art. $111 \S 1$ k.w. ,jeżeli rozpowszechniane, w tym również $\mathrm{w}$ prasie $\mathrm{w}$ rozumieniu prawa prasowego materiały wyborcze, w szczególności plakaty, ulotki i hasła, a także wypowiedzi lub inne formy prowadzonej agitacji wyborczej, zawierają informacje nieprawdziwe, kandydat lub pełnomocnik wyborczy zainteresowanego komitetu wyborczego ma prawo wnieść do sądu okręgowego wniosek o wydanie orzeczenia: zakazu rozpowszechniania takich informacji, przepadku materiałów wy-

urządzeń ogłoszeniowych nieusuniętych przez obowiązanych do tego pełnomocników wyborczych w terminie, o którym mowa $\mathrm{w} \S 6$. Koszty usunięcia ponoszą obowiązani".

37 Zgodnie z $§ 2$ tego przepisu Sąd okręgowy rozpoznaje wniosek, o którym mowa w $\S 1$, w ciagu 24 godzin w postępowaniu nieprocesowym. Sąd może rozpoznać sprawę w przypadku usprawiedliwionej nieobecności wnioskodawcy lub uczestnika postępowania, którzy o terminie rozprawy zostali prawidłowo powiadomieni. Postanowienie kończące postępowanie w sprawie sąd niezwłocznie doręcza wraz z uzasadnieniem osobie zainteresowanej, o której mowa w $\S 1$, i zobowiązanemu do wykonania postanowienia sądu. $Z$ kolei $\S 3$. Na postanowienie sądu okręgowego przysługuje w ciagu 24 godzin zażalenie do sądu apelacyjnego, który rozpoznaje je w ciagu 24 godzin. Od postanowienia sądu apelacyjnego nie przysługuje skarga kasacyjna i podlega ono natychmiastowemu wykonaniu. § 4. Publikacja sprostowania, odpowiedzi lub przeprosin następuje nie później w ciągu 48 godzin, na koszt zobowiązanego. W orzeczeniu sąd wskazuje prasę $\mathrm{w}$ rozumieniu ustawy z dnia 26 stycznia 1984 r. - Prawo prasowe, w której nastapić ma publikacja, oraz termin publikacji. $\S 5$. W razie odmowy lub niezamieszczenia sprostowania, odpowiedzi lub przeprosin przez zobowiązanego w sposób określony w postanowieniu sądu sąd, na wniosek zainteresowanego, zarządza opublikowanie sprostowania, odpowiedzi lub przeprosin w trybie egzekucyjnym, na koszt zobowiązanego. § 5a. Do sprostowania, odpowiedzi lub przeprosin publikowanych w programach nadawców radiowych lub telewizyjnych stosuje się przepisy ustawy z dnia 29 grudnia 1992 r. o radiofonii i telewizji dotyczące działalności reklamowej w programach telewizyjnych i radiowych, z tym że czas przeznaczony na ich publikację nie jest wliczany do dopuszczalnego wymiaru czasu emisji reklam określonego w art. 16 tej ustawy. 
borczych zawierających takie informacje, nakazania sprostowania takich informacji, nakazania publikacji odpowiedzi na stwierdzenia naruszające dobra osobiste, nakazania przeproszenia osoby, której dobra osobiste zostały naruszone, nakazania uczestnikowi postępowania wpłacenia kwoty do 100000 złotych na rzecz organizacji pożytku publicznego". Użycie w tym przepisie określenia „rozpowszechniane, w tym również w prasie w rozumieniu prawa prasowego", wyznacza w istocie zakres podmiotowy i przedmiotowy tego przepisu. Po pierwsze stanowi się tu o rozpowszechnianiu. Kodeks nie precyzuje tego pojęcia, choć takie definicje występują w innych aktach normatywnych. Wydaje się, że termin ten należy rozumieć w sposób podobny do tego, jaki nadaje mu prawo autorskie, a nie ustawa o radiofonii i telewizji ${ }^{38}$. Chodzi tu zatem o jakiekolwiek udostępnianie publiczności ${ }^{39}$. Drugą kwestią jest wykładnia pojęcia prasa w rozumieniu tego przepisu. Choć potocznie przyjmuje się, że w jego zakresie mieszczą się jedynie wydawnictwa drukowane periodyczne i rozpowszechniane w sieci publicznej ${ }^{40}$, to jednak w świetle art. 7 ust. 2 pkt 1 ustawy z dnia 26 stycznia 1984 r. Prawo prasowe, pojęcie to jest rozumiane znaczniej szerzej. Otóż zgodnie z przywołaną definicją ustawową ,prasa” oznacza ,publikacje periodyczne, które nie tworzą zamkniętej, jednorodnej całości, ukazujące się nie rzadziej niż raz do roku, opatrzone stałym tytułem albo nazwą, numerem bieżącym i datą, a w szczególności: dzienniki i czasopisma, serwisy agencyjne, stałe przekazy teleksowe, biuletyny, programy radiowe i telewizyjne oraz kroniki filmowe; prasą są także wszelkie istniejące i powstające w wyniku postępu technicznego środki masowego przekazywania, w tym także rozgłośnie oraz tele- i radiowęzły zakładowe, upowszechniające publikacje periodyczne za pomocą druku, wizji, fonii lub innej techniki rozpowszechniania"41. Jak z powyższego wynika, niezbędnymi przesłankami

38 W myśl art. 4 pkt 7 ustawy z dnia 29 grudnia 1992 r. o radiofonii $i$ telewizji (t.j. Dz. U. 2011, Nr 43, poz. 226 z późn. zm.) rozpowszechnianiem jest emisja programu drogą bezprzewodową lub przewodową do odbioru przez odbiorców.

39 Zgodnie z art. 6 ust. 1 pkt 3 ustawy z dnia 4 lutego 1994 r. o prawie autorskim i prawach pokrewnych (t.j. Dz. U. 2006, Nr 90, poz. 631 z późn. zm.) utworem rozpowszechnionym jest utwór, który za zezwoleniem twórcy został w jakikolwiek sposób udostępniony publicznie.

40 Tak Popularna, red. J. Skrzypczak, s. 426-427; podobnie Encyklopedia wiedzy o prasie, red. J. Maślanka, Wrocław-Warszawa-Kraków-Gdańsk 1976, s. 168.

${ }_{41}$ Tak art. 7 ust. 2 pkt 1 pr.pr. W doktrynie na tle definicji ustawowej wskazuje się trzy możliwe sposoby pojmowania pojęcia „prasa”, a mianowicie ,a) prasa 
konstytuującymi pojęcie prasy jest periodyczność, otwartość i różnorodność treści, określona częstotliwość ukazywania się (nie mniej niż raz do roku) oraz stały tytuł, numer bieżący i data ${ }^{42}$. $\mathrm{Z}$ powyższej definicji wynika niezbicie, że radiofonia i telewizja analogowa także mieści się w pojęciu ,prasa”. Stwierdzenie to odnosi się do wszelkich sposobów emisji programów znanych w erze przedcyfrowej, a więc przekazów naziemnych, ale także satelitarnych i kablowych. Wątpliwości pojawiają się jednak w przypadku oceny przekazów cyfrowych, a zwłaszcza internetowych. Zważywszy na różnorodność dostępnych form takiej działalności, rozważyć należy różne przypadki. Wydaje się, że odnośnie programów radiowych i telewizyjnych, nadawanych linearnie za pomoca platform naziemnych, satelitarnych i kablowych oraz mobilnych ocena będzie identyczna. Bardziej złożoną jest kwestia oceny medialnych usług nielinearnych. W tym przypadku odbiorca wybiera konkretną audycję, stąd po pierwsze trudno tu mówić o programie ${ }^{43}$, a po drugie o zrealizowaniu przesłanki periodyczności. Zwłaszcza ze względu na brak tej ostatniej cechy nie sposób przyjąć, że medialne usługi nielinearne są „,prasą”, nawet jeśli uwzględni się ten fragment definicji ustawowej, w którym mowa o powstających w wyniku postępu technicznego środkach masowego przekazywania, upowszechniających publikacje periodyczne za pomocą druku, wizji, fonii lub innej techniki rozpowszechniania. Ponadto mamy w takich przypadkach do czynienia z zamkniętą, jednorodną całością, co tym bardziej wyklucza zaliczenie tej kategorii do pojęcia „,prasa” w rozumieniu Prawa prasowego. Inna będzie natomiast ocena narrowcastingu, bowiem tu wymóg periodyczności, otwartości i różnorodności treści zostaje spełniony. Jednak największe spory dotyczą kategoryzowania w świetle powyższej definicji legalnej przekazów internetowych.

w znaczeniu przedmiotowym (będąca przekazem o określonych cechach), b) prasa w znaczeniu instytucjonalnym (utożsamiana ze środkami masowego przekazu) oraz c) prasa w znaczeniu podmiotowym (oznaczająca zespoły ludzi i poszczególne osoby zajmujące się działalnością dziennikarska)". Tak E. Czarny-Drożdżejko, Dziennikarskie dochodzenie prawdy a przestęstwo zniesławienia $w$ środkach masowego przekazywania, Kraków 2005, s. 195. Zob. także J. Skrzypczak, Polityka..., op. cit., s. $198 \mathrm{i} \mathrm{n}$.

42 I. Dobosz, Prawo prasowe. Podręcznik, Warszawa 2006, s. 75.

43 Zgodnie $\mathrm{z}$ art. 4 pkt 6 urtv program to ,usługa medialna stanowiąca uporządkowany zestaw audycji, przekazów handlowych lub innych przekazów, rozpowszechniany w całości, w sposób umożliwiający jednoczesny odbiór przez odbiorców w ustalonym przez nadawcę układzie". 
Otóż w doktrynie spotkać można bardzo różne stanowiska w tym zakresie. Odnajdziemy zatem wypowiedzi przedstawicieli nauki, w których przekonuje się, że treści zamieszczane w internecie nie mogą być w żadnym przypadku uznane za prasę. W tym nurcie mieści się stanowisko, które przekonuje, że z uwagi na brak przesłanki periodyczności w tego rodzaju przekazach, nie można ich traktować jako prasy ${ }^{44}$. Znacznie częściej spotkać można jednak mniej kategoryczne sądy, dopatrujące się bardziej złożonej sytuacji, choć konkluzje bywają różne. Zgodzić się należy natomiast z teza, że dzienniki i czasopisma z tego powodu, że ukazują się w internecie, nie tracą cech prasy. Dotyczy to zarówno sytuacji, gdy wersja internetowa jest niemal identyczna z ,wydaniem papierowym”, jak również, gdy funkcjonuje tylko w formie elektronicznej $\mathrm{w}$ sieci, ukazując się periodycznie ${ }^{45}$. Powyższe stanowisko w pełni koresponduje z ostatnimi poglądami judykatury ${ }^{46}$. Wydaje się, że linia orzecznicza jest

44 I. Dobosz, op. cit., s. 75. Spotkać można także opinie, które traktują internet w całości - wprawdzie nie jako prasę - ale jako środki masowego komunikowania. Tak Kodeks karny. Część szczególna. Komentarz do art. 117-277 Kodeksu karnego, red. A. Zoll, Kraków 1999, s. 647. Dodać tu trzeba, że powyższy pogląd został sformułowany na tle art. $212 \S 2$ k.k., który przewiduje kwalifikowany typ przestępstwa zniesławienia, jeżeli sprawca dopuszcza się czynu za pomocą ,środków masowego komunikowania". Podobne wnioski, ale już na gruncie prawa prasowego prezentują J. Maciag, S. Stanisławska, Internet - prasa - prawo, „ZN UJ PzWiOWI”, 1997, z. 68, s. 89; K. Święcka, J. S. Święcki, Dyferencjacje prawne pojęcia „,media”, „Rocznik Nauk Prawnych” 2006, t. XVI, nr 1, s. 455. Patrz szerzej J. Skrzypczak, Polityka..., op. cit., s. 198 i n.

45 J. Sobczak, Prawo, teza 3 do art. 7, s. 318-319. Zdaniem J. Barty „O ile dyskusyjne może być zaliczanie Internetu do prasy, a nawet środków masowego przekazu, o tyle znacznie łatwiej zgodzić się, iż informacje podawane za jego pośrednictwem, z wyłączeniem komunikacji indywidualnej (jak przy poczcie elektronicznej), są - w rozumieniu prawa - informacjami podawanymi do publicznej wiadomości. Ten punkt widzenia wywołuje skutki prawne w obszarze tych wszystkich regulacji, które posługują się tak właśnie sformułowaną przesłanką [...] Periodycznie wprowadzane i rozpowszechniane w Internecie materiały można traktować jako prasę w rozumieniu ustawy z 1984 r.”. J. Barta, Problem goni problem, „Rzeczpospolita” 1998, nr 4, s. 15. Podobnie E. Nowińska, M. du Vall, Komentarz do ustawy o zwalczaniu nieuczciwej konkurencji, Warszawa 2001, s. 184; E. Nowińska, Nieuczciwa reklama w Internecie, w: Internet - problemy prawne, red. R. Skubisz, Lublin 1998, s. 51; E. Ferenc-Szydełko, op. cit., s. 79-80. Zob. także J. Skrzypczak, Polityka ..., op. cit., s. $198 \mathrm{i} \mathrm{n}$.

${ }^{46}$ I tak w postanowieniu SN z dnia 26 lipca 2007 r. zauważono, że „osoba rozpowszechniająca bez rejestracji we właściwym sądzie okręgowym dziennik bądź czasopismo za pośrednictwem Internetu zarówno wówczas, gdy przekaz taki towa- 
obecnie ugruntowana ${ }^{47}$, choć $\mathrm{w}$ przeszłości pojawiały się w tej materii

rzyszy przekazowi utrwalonemu na papierze, stanowiąc inną elektroniczną jego postać, jak i wówczas, gdy istnieje tylko formie elektronicznej w Internecie, wyczerpuje znamiona przestępstwa z art. 45 ustawy - Prawo prasowe”. Zob. Postanowienie SN z dnia 26 lipca 2007 r. (sygn. akt IV KK 174/2007), „Orzecznictwo Sądu Najwyższego w Sprawach Karnych” 2007, poz. 1737. Zob. także glosę aprobująca J. Taczkowskiej, „OSP” 2008, nr 6, s. 414 oraz krytyczną E. Czarny-Drożdżejko, Glosa, s. 84, a także W. Górowskiego, „PiP” 2008, nr 6, s. 127.

${ }^{47}$ Przywolać należy tu Postanowienie SN z 7 maja 2008 r. (sygn. akt III KK 234/87), opublik. w „Biul. PK” 2008, nr 10, s. 33, gdzie wyrażono pogląd (tak tezy 2 i 4), iż „Internetowy przekaz o charakterze periodycznym, spełniający wymogi przewidziane przez ustawodawcę $\mathrm{w}$ treści art. 7 ust. 2 pkt 1 [...] p.pr. niewątpliwie jest prasą. [...] Środkami masowego komunikowania będą wszystkie środki, których działanie sprowadza się do masowego przekazywania rozmaitych treści. Czyli do środków tych wypadnie zaliczyć nie tylko prasę drukowaną, przekaz radiowy i telewizyjnych lecz także książkę, plakat, film oraz przekaz za pomocą Internetu [...]”. Wymienić w tym nurcie należy stanowisko wyrażone w Wyroku Sadu Rejonowego w Stupsku z dnia 16 grudnia 2008 r. (sygn. akt II K 367/2008), opublik. „LexPolonica" nr 2077260. W uzasadnieniu tego orzeczenia podkreślono, że ,już z wyjaśnień samego oskarżonego wynikało, iż jego działalność w ramach portalu internetowego [...] stanowiła prasę w rozumieniu Prawa prasowego". Jednocześnie warto odnotować tu tezę, iż „Stworzenie samej możliwości komentowania bieżących zdarzeń, zabierania głosu w dyskusji toczącej się na tematy poruszane w prasowej działalności portalu, nie może być postrzegane w kategoriach publikowania materiałów prasowych. Trudno również uznać, aby intencją uczestników dyskusji było coś więcej niż zabranie głosu w trwającej debacie, a przez to ukazanie się ich komentarzy na forum, nie zaś publikowanie ich treści w rozumieniu Prawa prasowego. Ustawa wymaga tymczasem, aby dany materiał został opublikowany lub przekazany do opublikowania w prasie (art. 7 ust. 2 pkt 4 pr.pr.). 2. Stworzenie forum dyskusyjnego jako miejsca permanentnej dyskusji, dialogu, wymiany poglądów przez użytkowników portalu, ich aktywny i wyłączny udział w kreowaniu treści dostępnych zarówno dla innych uczestników debaty, jak też biernych obserwatorów, przy ograniczonej kontroli i ingerencji prowadzącego portal sprawia, że nie sposób tego ostatniego za treść toczącej się dyskusji obarczać odpowiedzialnością karną statuowaną przez treść art. 49a Prawa prasowego". Na uwage zasługuje także Postanowienie WSA w Warszawie z dnia 30 października 2008 r., sygn. akt II S.A./WA 1885/07, opublik. LEX nr 521930), gdzie w t. 2 wyrażono następujący pogląd: „Periodyki internetowe, by mogły być uznane za wydawnictwa prasowe, wcale nie muszą mieć postaci typowych gazet elektronicznych, których wydawcami są tylko wielkie koncerny prasowe, firmujące jedynie znane tytuły publikatorów w systemie on line. O tym czy publikacja internetowa ma charakter prasowy decydować powinien cel, jakiemu ma służyć. Skoro rolą i zadaniem prasy jest rozpowszechnianie informacji, to periodyczność przekazu, czyli cyklicznego informowania opinii publicznej o określonych faktach społecznych, ekonomicznych, gospodarczych, politycznych, oświatowych, 
różne stanowiska ${ }^{48}$. Podsumowując tę dyskusję należy przyjąć pogląd, iż „Internet jest tylko środkiem przekazu, podobnie jak ryza papieru. Papieru jako takiego nikt nie może rejestrować, natomiast rejestracji podlega papier zadrukowany, a w zasadzie nie sam papier, lecz tylko działalność polegająca na zadrukowywaniu papieru i wydawaniu go w formie dziennika bądź czasopisma - a więc prasy"49. Reasumując, stwierdzić wypada, że „w takiej sytuacji można mówić nie o Internecie jako prasie, lecz o prasie w Internecie" ${ }^{\text {50 }}$. Zważywszy nadto, iż analizowana przesłanka to „rozpowszechnianie, $\mathrm{w}$ tym również $\mathrm{w}$ prasie $\mathrm{w}$ rozumieniu prawa prasowego", pomijając wątpliwości związane z prawidłową wykładnią „prasa”, nie ma wątpliwości, że ten tryb będzie mógł być stosowany do wszelkich sposób przekazów internetowych udostępnianych publiczności, bez względu na to czy mamy do czynienia z prasą. Obejmie zatem wszelkiego rodzaju media społecznościowe, blogi ${ }^{51}$ itp.

kulturalnych z zakresu muzyki, filmu i sztuki, etc. pod oznaczonym tytułem, nazwa, adresem czy nawet linkiem, wskazywać będzie na cel, jaki realizuje redakcja, wydawca czy autor danej publikacji elektronicznej, na stworzonej specjalnie w tym celu stronie internetowej”. Por. także orzeczenie SN z 15.12.2010r. (sygn. akt III K 250/10). Komunikat na ten temat został zamieszczony na stronie http://www.sn.pl/aktual/index.html. Patrz szerzej J. Skrzypczak, Polityka ..., op. cit., s. 198 i n.

${ }^{48} \mathrm{~W}$ niektórych przypadkach sądy odmawiały rejestracji dzienników i czasopism internetowych (np. Postanowienie SA w Rzeszowie z 25 maja 2005 r., I ACa 277/05, Postanowienie SO w Krośnie z 17 marca 2005 r., I Ns.Rej.Pr. 3/05), w innych stanowisko było odmienne (patrz Postanowienie SO w Poznaniu z 30 czerwca 2005 r., I Ns.Rej.Pr 75/05, Postanowienie SO w Warszawie z 17 lutego 2005 r., VII Ns.Rej.Pr. 69/05). Powyższe orzeczenia przytacza Balcarczyk, op. cit., s. 30-33. Patrz także Materiaty pokonferencyjne Centrum Monitoringu Wolności Prasy, „Prasa w Internecie”, CD. Patrz szerzej J. Skrzypczak, Polityka..., op. cit., s. 198 i n.

49 J. Sobczak, Prawo, s. 319.

50 E. Nowińska, Prasa drukowana, w: Prawo mediów, red. J. Barta, R. Markiewicz, A. Matlak, op. cit., s. 96. Podobnie S. Jankiewicz, Prowadzenie reklamy w Internecie, „Radca Prawny” 2001, nr 2, s. 40. W takim razie należałoby zgodzić się $\mathrm{z}$ tezą zaprezentowaną przez T. Longa w 2004 r. w kalifornijskim magazynie „Wired”, iż internet należy pisać małą litera, skoro jest to „tylko” kolejne medium, takie jak radio lub telewizja. Patrz szerzej L. Olszański, op. cit., s. 9 oraz J. Skrzypczak, Polityka..., op. cit., s. 198 i n.

${ }^{51}$ „Blogowanie” (blogging) to „skrót od web-logging, termin, który początkowo odnosił się do platformy technologicznej, umożliwiającej łatwą i szybką aktualizację treści na stronach internetowych. Stopniowo zmienił znaczenie i dziś określa sposób publikacji, który ma korzenie amatorskie, ale związany jest z informacjami dystrybuowanymi zarówno przez innych blogerów, jak i media głównego nurtu”. H. Jen- 
Inna musi być wykładnia art. 112 kodeksu wyborczego. Zgodnie bowiem z tym przepisem „Informacje, komunikaty, apele i hasła wyborcze, ogłaszane w prasie drukowanej na koszt komitetów wyborczych muszą zawierać wskazanie, przez kogo są opłacane i od kogo pochodzą. Odpowiedzialnym za umieszczenie tego wskazania jest redaktor w rozumieniu ustawy z dnia 26 stycznia 1984 r. - Prawo prasowe”. Pojawia się tu określenie prasy drukowanej, które - co ciekawe- nie ma przecież charakteru normatywnego. Wydaje się, że takie ujęcie dotyczy jedynie „papierowych” wydań gazet, choć z pewnością może budzić zdziwienie takie ograniczenie.

Rozdział 13 kodeksu wyborczego poświęcony został kampanii wyborczej w programach nadawców radiowych i telewizyjnych. Warto jednak zaznaczyć w erze cyfrowej, mimo obowiązującej ustawy z 29 grudnia 1992 r. $^{52}$, pojęcia radiofonii i telewizji stają się anachroniczne ${ }^{53}$. W myśl postanowień art. $117 \S 1$ k.w. komitetom wyborczym, których kandydaci zostali zarejestrowani przysługuje, w okresie od 15 dnia przed dniem wyborów do dnia zakończenia kampanii wyborczej, prawo do rozpowszechniania ${ }^{54}$

kins, op. cit., s. 252. Blog to dzisiaj zwykle rodzaj internetowego pamiętnika, prezentującego emocje i doświadczenia autora, a także często zawierającego informacje i opinie właściwie z każdej sfery życia społecznego. Bardzo często stanowią one inspirację dla materiałów prasowych zamieszczanych w tradycyjnych mediach. Zob. szerzej na ten temat J. M. Zając, K. Rakocy, Blogi i blogosfera z perspektywy sieci społecznych, „Studia Medioznawcze” 2007, nr 3, s. 80-81; J. Skrzypczak, Polityka..., op. cit., s. 198 i n.

${ }^{52}$ Ustawa z dnia 29.12.1992 r. o radiofonii i telewizji (t.j. Dz. U. 2011, Nr 43, poz. $226 \mathrm{z}$ późn. zm.).

${ }^{53}$ Definicje tych pojęć, powstałe jeszcze $\mathrm{w}$ erze analogowej, wydają się nie uwzględniać obecnej różnorodności form i możliwości świadczenia usług medialnych. Aktualność jednak zachowuje konstatacja, że „radio” to przekazywanie na odległość materiałów dźwiękowych, a „telewizja” - ruchomych obrazów zwykle z dźwiękami. Jednak dystrybucja sygnału odbywa się obecnie już nie tylko za pomocą fal elektromagnetycznych, ale także za pomocą przekazów internetowych. Dodać trzeba, że w dobie konwergencji „radio” coraz częściej upodabnia się do „telewizji”, oferując na stronach internetowych nie tylko dźwięk, ale i obrazy. Ponadto „konsumpcja" przekazów radiowych i telewizyjnych odbywać się może nie tylko za sprawą odbiornika rtv, ale także za pomocą komputera, telefonu komórkowego lub innego urzadzenia. Zob. szerzej na ten temat J. Skrzypczak, Polityka ..., op. cit., s. 198-201.

${ }^{54}$ Przez pojęcie rozpowszechniania nieodpłatnie audycji wyborczych rozumie się zarówno rejestrację i emisję wystąpień przedstawicieli komitetów wyborczych bądź kandydatów, jak i rejestrację oraz emisję audycji wyborczych przygotowanych przez komitety wyborcze (tak art. $117 \S 2$ k.w.). 
nieodpłatnie audycji wyborczych ${ }^{55}$, w programach publicznych nadawców radiowych i telewizyjnych na koszt tych nadawców. Pojawia się chociażby wątpliwość o jakie programy nadawców publicznych chodzi. Czy tylko o te, o których mowa w ustawie o radiofonii i telewizji ${ }^{56}$, czy także o programy tematyczne? Wydaje się jednak, że chodzi wyłącznie o tę pierwszą kategorię. Powyższe rozwiązania uzupełniają przepisy zabraniające odstępowania czasu antenowego innemu komitetowi wyborczemu (art. $117 \S 4 \mathrm{kw}$ ) oraz wplatania treść audycji wyborczych stanowiących agitację wyborczą na rzecz innego komitetu wyborczego lub jego kandydatów (art. $117 \S 5$ k.w.).

Podkreślić należy, iż po raz pierwszy w naszym porządku prawnym kodeks wyborczy podjął problem z pewnością najbardziej popularnych „gatunków wyborczych”, a mianowicie debat wyborczych. Otóż zgodnie z art. $120 \S 1$ k.w. Telewizja Polska S.A. ma obowiązek przeprowadzenia debat pomiędzy przedstawicielami komitetów wyborczych w wyborach do Sejmu lub w wyborach do Parlamentu Europejskiego w Rzeczypospolitej Polskiej, które zarejestrowały swoje listy kandydatów we wszystkich okręgach wyborczych, a w przypadku wyborów Prezydenta Rzeczypospolitej - pomiędzy kandydatami. Czas debat nie jest wliczany do czasu antenowego, o którym mowa w art. 117 k.w.

W kontekście poruszanej tu problematyki, pewne wątpliwości może budzić także art. $122 \S 1 \mathrm{k} . w$. Otóż zgodnie z tym przepisem publiczni nadawcy radiowi i telewizyjni zapewniają Państwowej Komisji Wyborczej oraz komisarzom wyborczym, w okresie od dnia ogłoszenia aktu o zarządzeniu wyborów do dnia głosowania, możliwość przedstawienia nieodpłatnie, w programach ogólnokrajowych oraz regionalnych informacji, wyjaśnień i komunikatów związanych z zarządzonymi wyborami oraz obowiązującymi w danych wyborach przepisami prawnymi. Także

55 Audycją wyborczą jest część programu radiowego lub telewizyjnego, niepochodząca od nadawcy, stanowiąca odrębną całość ze względu na treść lub formę (zob. art. $117 \S 3$ k.w.).

${ }^{56}$ Zgodnie z art. 26 ust. 2 telewizję publiczną tworzy spółka „Telewizja Polska - Spółka Akcyjna", zawiązana w celu tworzenia i rozpowszechniania ogólnokrajowych programów I, II i TV Polonia oraz regionalnych programów telewizyjnych. Z kolei zgodnie z ust. 3 tego przepisu radiofonię publiczną tworzą: 1) spółka „Polskie Radio - Spółka Akcyjna", zawiazzana w celu tworzenia i rozpowszechniania ogólnokrajowych programów radiowych i programów dla odbiorców za granicą; 2) spółki zawiązane w celu tworzenia i rozpowszechniania regionalnych programów radiowych. 
w tym przypadku rodzi się wątpliwość jak ten obowiązek powinien być realizowany, a w szczególności czy powyższe obowiązki powinny być wykonane za pomocą jedynie programów, o których mowa w ustawie o radiofonii i telewizji, czy też (a może tylko) na „nowych antenach”.

Na koniec warto przypomnieć, iż na mocy wyroku Trybunału Konstytucyjnego z dnia 20 lipca 2011 r. (sygn. akt K 9/11), zakwestionowano m.in. art. $119 \S 1$ k.w. zabraniający rozpowszechniania odpłatnie ogłoszeń wyborczych ${ }^{57} \mathrm{w}$ programach publicznych i niepublicznych nadawców radiowych i telewizyjnych. Uznano, że przepis ten jest niezgodny z art. 54 ust. $1 \mathrm{w}$ związku z art. 31 ust. 3 Konstytucji. Trybunał w uzasadnieniu podkreślił, „że w art. 54 Konstytucji, którego treść jest często w skrócie określana jako «wolność słowa», zostały wyrażone trzy wolności, wzajemnie powiązane: a) wolność wyrażania swoich poglądów, b) wolność pozyskiwania informacji, c) wolność rozpowszechniania informacji ${ }^{58}$. [...] Wolność wyrażania swoich poglądów i wolność rozpowszechniania informacji w kontekście praktykowania demokracji, w tym zwłaszcza w okresie wyborów, ma znaczenie przede wszystkim dla partii politycznych i tworzonych przez nie oraz przez koalicje partii politycznych lub przez wyborców komitetów wyborczych. A wolność pozyskiwania informacji to przede wszystkim prawo obywateli jako wyborców, którzy powinni jak najwięcej wiedzieć o podmiotach biorących udział w wyborach i o kandydatach, jeśli mają świadomie wybierać. Wyrażanie poglądów w sferze publicznej to m.in. uzewnętrznianie ocen, opinii i postulatów oraz prognoz i przypuszczeń dotyczących działalności władz i funkcjonariuszy publicznych czy partii politycznych, a także koncepcji rozwiązywania różnych problemów politycznych lub społecznych. Należy zwrócić uwagę, że art. 54 ust. 1 Konstytucji stanowi o wyrażaniu swoich poglądów, jednakże przyjmuje się, że cudze poglądy można rozpowszechniać jako informacje ${ }^{59}$. Poglądy można wyrażać w różny sposób, nie tylko słownie (mówiąc lub pisząc), lecz także za pomocą obrazów,

57 Przy czym w $\S 2$ tego przepisu zdefiniowano, iż pod pojęciem ogłoszenia wyborczego należało rozumieć część programu radiowego lub telewizyjnego, niepochodzącą od nadawcy, stanowiącą odrębną całość ze względu na treść lub formę, której emisja została zlecona przez komitet wyborczy w ramach prowadzonej kampanii wyborczej.

58 Zob. wyrok z 5 maja 2004 r., sygn. P 2/03, OTK ZU nr 5/A/2004, poz. 39. Por. też P. Sarnecki, Uwagi do art. 54 Konstytucji, w: Konstytucja Rzeczypospolitej Polskiej. Komentarz, red. L. Garlicki, t. 3, Warszawa 2003, s. 3.

59 P. Sarnecki, op. cit., s. 3. 
w tym różnego rodzaju plakatów, a nawet nosząc określony ubiór lub odznaki. Przez rozpowszechnianie informacji rozumie się zarówno udostępnianie posiadanych informacji (danych) indywidualnie wytypowanym osobom trzecim, jak i ich upowszechnianie, czyli podawanie do wiadomości publicznej, w tym za pośrednictwem środków społecznego przekazu. Wolność pozyskiwania informacji jest to wolność poszukiwania informacji na własną rękę, z zastosowaniem wszelkich sposobów mieszczących się w granicach ustaw. Nie ulega wątpliwości, że w obecnej dobie głównymi źródłami pozyskiwania informacji i ich rozpowszechniania są środki społecznego przekazu, a najważniejszymi - media elektroniczne. W sferze prywatnej zarówno wolność pozyskiwania informacji, jak i rozpowszechniania informacji doznają licznych ograniczeń wynikających z norm chroniących różne wolności osobiste, w szczególności prawo do prywatności. W sferze publicznej granice wolności słowa $\mathrm{w}$ tej postaci są znacznie szersze"60. Trybunał pominął jednak pewien wątek, który zważywszy na zakwestionowanie tych przepisów okazał się nieistotny, który jednak zważywszy na prezentowaną tu problematykę zasługuje na szczególne uwypuklenie. Otóż przepis ten posługiwał się pojęciem programów publicznych i niepublicznych nadawców radiowych i telewizyjnych. Jak już wyżej sygnalizowano, postęp techniczny powoduje, że problemy pojawiają się także w przypadku definiowania radiofonii i telewizji.

Jak wyżej próbowano wykazać kodeks wyborczy, czyli akt normatywny przyjęty w 2011 r., a więc w erze cyfrowej, w zasadzie ignoruje istnienie „nowych mediów”. Możliwe jest wprawdzie w części przypadków stosowanie wykładni rozszerzającej, obejmującej również te przypadki. W każdej sytuacji stwarza to jednak szereg wattpliwości i poczucie niepewności prawnej. Można oczywiście założyć, że ustawodawca w sposób świadomy rezygnuje z regulowania tej materii, zgodnie z założeniem, że zwłaszcza internet powinien być raczej poddany samoregulacji niż ingerencji ustawodawcy. Analizując jednak proces legislacyjny, trzeba przyznać, że jest to założenie dość naiwne. To jednak powoduje, zważywszy na zmiany rynku medialnego, że przyjęte rozwiązania legislacyjne w dość krótkim czasie mogą okazać się bez znaczenia dla głównego nurtu kampanii wyborczych.

60 Uzasadnienie wyroku TK z dnia 20 lipca 2011 r. (sygn. akt K 9/11). 


\title{
Election campaigns in the media - legal considerations
}

\begin{abstract}
Summary
One of the most interesting social phenomena in the field of social communication, that is the emergence of the new media in the $21^{\text {st }}$ century, has obviously been noted and used by election committees. The paper tries to analyze whether this phenomenon has been similarly noted and accounted for by Polish legislators. An impulse for these considerations was additionally provided by the Act of 5 January 2011 on the Election Code passed in 2011. This normative act has been adopted in the digital era but it virtually ignores the presence of the 'new media'. While it is true that the interpretation of some regulations may be broadened to include them as well, this will likely generate numerous doubts and a sense of legal uncertainty. Given the transformations in the media market, the legal solutions adopted may soon turn out to be irrelevant to the main course of election campaigns.
\end{abstract}


